\title{
Do companies in the Czech Republic feel a decline in ICT graduates?
}

\author{
Jiř́ Kučera ${ }^{1 *}$, Yaroslava Kostiuk ${ }^{1}$, and Daniel Kortiš ${ }^{2}$ \\ ${ }^{1}$ University of Žilina, The Faculty of Operation and Economics of Transport and Communications, \\ Department of Economics, Univerzitná 8215/1, 01026 Žilina, Slovakia \\ ${ }^{2}$ Institute of Technology and Business in České Budějovice, School of Expertness and Valuation, \\ Okružní 517/10, 37001 České Budějovice, Czech Republic
}

\begin{abstract}
The aim of this paper is to determine the possible cause of lagging Czech companies in the field of HR transformation. The basic source of data is data from the Czech Statistical Office. The paper uses the method of classification analysis of graduates in the field of information and communication technologies. The paper is divided into two parts, where the first part deals with the evaluation of tabular data and the second with the testing of the established hypothesis (H0). The number of graduates in the field of information and communication technologies in the Czech Republic has been steadily declining since 2015 , although the results achieved so far do not indicate a significant change, which could be the main cause of Czech companies lagging behind in HR transformation. The low involvement of graduates in this field is also caused by older and backward employees in companies, who do not like to change established systems.
\end{abstract}

Keywords: graduates, digital transformation, information and communication technologies, human resource management

JEL codes: A22, A23, O15, O31

\section{Introduction}

So far, the digital transformation in HR (Human Resources) is rather reminiscent of backward or outdated practices. Everyone is waiting for the change to come on its own, but on the contrary, there is nothing to wait for [1]. Nothing will come by itself; you need to start working on it. ICT (Information and Communication Technologies) are already so advanced that this cannot be overlooked even in the field of HR. The next generation of workers has been coming to work for many years with a mobile phone and with certain expectations, but the request for days off work is still written out on paper or sent by e-mail. Managers always fill in the same Excel forms sent back and forth. The only thing that hinders the digital transformation in HR is the rigid thinking of HR and IT (Information Technology) departments [2].

Anyone who monitors technological development, if only a little, will admit that it has exceeded expectations, for better or worse. Today, it is not a question of whether or not something can be technologically solved [3]. It is a question of the extent to which employees

*Author's contact information: kuceraj@mail.vstecb.cz 
are informed about technological innovations and whether they are willing to participate in the digital transformation themselves [4]. The digital transformation cannot be imagined without disturbing established work orders. Of course, the digital transformation in the corporate sphere follows different rules than in the private sphere. They differ in terms of the goal to be achieved and also in motivation [5].

The digital transformation in the company environment in the field of HR is specific, in many companies it is delayed or has not even started at all. Even so, recording information in many complicated Excel spreadsheets, searching hundreds or thousands of e-mail messages, or constantly redrawing the organizational structure in PowerPoint cannot provide 21 st-century productivity.

The digital transformation in the HR area is often delayed not only in smaller, but also in a number of medium-sized, and especially large companies, where the effects on productivity are evident [6]. Despite the visible development of ICT technologies, business practice in the HR field remains stuck on models 20 to 30 years old. It is not difficult to find and eliminate the causes under one assumption if there is someone in the company who recognizes the opportunity in the digital transformation of HR technologies [7].

Today, ICT technologies in the Czech Republic are somewhat backwards compared to other countries, in my opinion mainly because young people devoted to ICT do not get many opportunities in their jobs, because companies do not like to change established and used procedures. Another reason can also be considered the lack of graduates in ICT fields, which would mean that companies do not have the opportunity to keep up with the times in the field of HR.

The aim of this paper is to determine the possible cause of Czech companies lagging behind in the field of HR transformation.

For this purpose, the following research question (RQ) was formulated:

- RQ1: How many students graduated in the field of ICT?

Furthermore, the null hypothesis (H0) will be tested:

- H0: The composition of the total number of graduates did not change during the monitored years.

Otherwise, the alternative hypothesis (H1) will be valid.

- H1: Companies in the Czech Republic will not be able to keep up with other countries, due to significant changes in the level of education of graduates of ICT fields.

\section{Literature research}

Because automation and structural transformation mark the new digital reality of the $21 \mathrm{st}$ century, today's organizations require a highly resilient and committed workforce to maintain a competitive advantage [8]. At the turn of the century and millennium, humanity faces global challenges, which it seeks to understand and to which it seeks theoretical and practical answers [9]. The spread of digital technologies increases the density of the communication network between all parties, devices, people and institutions involved [10]. Through digital transformation, small service businesses seek to increase their competitive advantage, improve business performance, and achieve business growth [11].

The development of artificial intelligence and digital transformation has brought with it the challenge of harnessing the potential of transformation of human resources (HR) processes, systems and organizations through new digital platforms, applications and ways of providing services [12]. The aftermath of the Covid-19 pandemic has caused a deep global economic downturn and a major rethink of enterprise technology [13]. Digital transformation processes have intensified, which is reflected in the development of global supply chains [14]. 
An increasing number of companies are moving forward in the digital transformation, which is the creation of new systems that connect people, things and companies with digital technologies [15]. Strohmeier [16] focuses on conceptual clarification of digital human resource management and related concepts of digitization of human resource management, referring to the general literature on digital organizations to develop terminology and typology, which together clarify the concept of digital human resource management and related concepts.

Hajnic and Boshkoska [12] introduce a method implemented in a decision support platform for employee transfer developed to address three constraints. The proposed platform is designed to process all available information and human-defined rules to support HR managers in planning and organizing their strategic activities in a timely manner, speed up the candidate selection process in the organization for more than $82 \%$, provide some of the best alternatives for employee utilization, reduce operating costs by more than $87 \%$ and reduce the administrative burden of human resource management.

Dahlbom et al. [17] discuss the implications of role transformation, HR-induced human resource functions. These are qualitative interviews in nine leading Finnish companies. The results show that both technical and human barriers, working with very basic HR processes and traditional information systems and poor data quality and hindering the adoption of advanced HR, further point to the need for increased collaboration with data analysts and HR professionals in providing and understanding data related to HR for business decision making.

Caputo et al. [18] explore the relationship between soft skills, information technology and Big Data in order to create a possible bridge capable of connecting human and technological dimensions to increase company performance. Using the Business-Inventory of Personality, the working personality of 4,758 human resources involved in 72 high-tech European companies was analyzed and its relationships with companies' investments in Big Data and the economic performance of companies were tested using structural equations. The results show the existence of strong relationships between some elements of the human resources personality, such as work motivation and social competences and the economic performance of companies. At the same time, they also clarify the mediated effect of investing in Big Data in the relationship between the organizational behavior of human resources and the economic performance of companies.

Intelligent manufacturing is a general concept that is constantly evolving [19]. Del Giudice et al. [20] analyze the impact of circular economy practices on company performance in the circular supply chain and examine the moderating role that the big data supply chain plays in these relationships. They use data collected through an online survey distributed to managers of 378 Italian companies that have adopted the principles of the circular economy. The results provide a number of original contributions to the practices of circular economy in a supply chain based on big data and provide useful insights, as well as taking on the challenge of capturing digital transformation trends and expanding sustainability research in supply chain management, further enhancing the literature by examining relationships between three different types of circular economy supply chain practices and company performance and also clarify the moderating role of big data in decision making and implementing circular supply chain solutions to achieve better environmental, social and economic benefits.

Choain et al. [21] claim that a professional services company has implemented Richard Florida's "Florida class" concept from the urban to the corporate environment for organizational change. Talent, technology and tolerance make up a high-value triptych driving the growth and attractiveness of the city - HR can appropriate it to bring about profound changes in the company's management and culture. Therefore, the return on experience from the project, which was implemented in the course of one year in the company 
Mazars, is presented here. The results offer a model for identifying members of the "creative class" in the corporate environment and a tried and tested approach to integrating the "creative class" into the exclusive and institutional exercise of the determination strategy.

The assessment of psychosocial risks at work aims to carry out interventions in the field of health protection at work based on the assessment of working conditions. However, it is expected that the ongoing industrial digitization will be accompanied by a fundamental transformation of these working conditions. The results of qualitative interviews are critically reflected and build on existing research [22].

\section{Data and methods}

As mentioned in the introduction, the biggest weakness of ICT technology may be the inaction of the employer to involve young graduates in individual positions or research. The second proclaimed assumption is the lack of graduates of the ICT field.

Data from the Czech Statistical Office will be used and analyzed to find answers to the set research questions. Here, a classification analysis of students' involvement in the fields of ICT technology will be performed. The analysis itself will be divided into two parts, the first of which will be the evaluation of tabular data, in which we have data that divide our graduates from several perspectives. The first aspect divides graduates according to whether they have foreign or Czech citizenship. The second aspect will be the level of education completed within the education system (Bc., Ing. / Mgr., Ph.D.). This will find the answer to VO1.

The second part of the analysis will consist of a percentage expression from the above points of view. Furthermore, a statistical test of the set of analyzed that will be used. Specifically, the chi square test will be used to confirm or refute the established null hypothesis $(\mathrm{H} 0)$.

\section{Results}

The table below presents data obtained from the Czech Statistical Office. Data is from 20102019 , more current data for 2020 is not yet available.

Table 1. Graduates of ICT fields from universities in the Czech Republic

\begin{tabular}{|c|c|c|c|c|c|c|c|c|c|c|}
\hline & $\mathbf{2 0 1 0}$ & $\mathbf{2 0 1 1}$ & $\mathbf{2 0 1 2}$ & $\mathbf{2 0 1 3}$ & $\mathbf{2 0 1 4}$ & $\mathbf{2 0 1 5}$ & $\mathbf{2 0 1 6}$ & $\mathbf{2 0 1 7}$ & $\mathbf{2 0 1 8}$ & $\mathbf{2 0 1 9}$ \\
\hline Total & 3787 & 3928 & 4225 & 4762 & 4468 & 4599 & 4361 & 3916 & 3802 & 3638 \\
\hline Citizenship & & & & & & & & & & \\
\hline Czech & 3259 & 3352 & 3646 & 4024 & 3822 & 3831 & 3550 & 3131 & 2921 & 2668 \\
\hline Foreign & 528 & 576 & 579 & 738 & 646 & 768 & 811 & 785 & 881 & 970 \\
\hline $\begin{array}{c}\text { Study } \\
\text { program }\end{array}$ & & & & & & & & & & \\
\hline $\begin{array}{c}\text { Associate } \\
\text { degree }\end{array}$ & - & - & - & 258 & 214 & 249 & - & - & - & - \\
\hline Bachelor's & 2503 & 2529 & 2543 & 2596 & 2479 & 2554 & 2291 & 2080 & 2055 & 1989 \\
\hline Master's & 1205 & 1326 & 1599 & 1817 & 1696 & 1703 & 1986 & 1750 & 1667 & 1580 \\
\hline Doctoral & 79 & 73 & 83 & 92 & 79 & 93 & 84 & 86 & 80 & 69 \\
\hline
\end{tabular}

Source: Czech Statistical Office, 2021, processed by authors.

From the above table, it is clear at first glance that the number of ICT graduates in the Czech Republic has been declining since 2015. Over the last four years, there has been a 
decrease from 4,599 graduates to 3,638 graduates. It is interesting that the number of foreign graduates, on the other hand, is constantly increasing. And as for the last evaluation, according to the studied program, most graduates completed a bachelor's degree program, while the overall shares in individual levels of education do not differ much, as shown in Table 2. Data in 2010-2012 and 2016-2019 did not contain information on the number of graduates Associate degree.

Table 2. Graduates of ICT fields from universities in the Czech Republic in percentage

\begin{tabular}{|c|c|c|c|c|c|c|c|c|c|c|}
\hline $\begin{array}{l}\text { Study } \\
\text { program }\end{array}$ & $\mathbf{2 0 1 0}$ & $\mathbf{2 0 1 1}$ & $\mathbf{2 0 1 2}$ & $\mathbf{2 0 1 3}$ & $\mathbf{2 0 1 4}$ & $\mathbf{2 0 1 5}$ & $\mathbf{2 0 1 6}$ & $\mathbf{2 0 1 7}$ & $\mathbf{2 0 1 8}$ & $\mathbf{2 0 1 9}$ \\
\hline $\begin{array}{c}\text { Associate } \\
\text { degree }\end{array}$ & - & - & - & 5,41 & 4,78 & 5,41 & - & - & - & - \\
\hline Bachelor's & 66,09 & 64,38 & 60,18 & 54,51 & 55,48 & 55,53 & 52,53 & 53,11 & 54,05 & 54,67 \\
\hline Master's & 31,81 & 33,75 & 37,84 & 38,15 & 37,95 & 37,02 & 45,54 & 44,68 & 43,84 & 43,43 \\
\hline Doctoral & 2,08 & 1,85 & 1,96 & 1,93 & 1,76 & 2,02 & 1,92 & 2,19 & 2,1 & 1,89 \\
\hline Total & 100 & 100 & 100 & 100 & 100 & 100 & 100 & 100 & 100 & 100 \\
\hline
\end{tabular}

Source: Czech Statistical Office, 2021, processed by authors.

Based on the above tables, it can be stated that the proportions of graduates of individual levels of education do not differ significantly, despite the declining total number of graduates of ICT disciplines.

However, this statement was tested using the chi square test. A significance level of p 5\% was chosen. According to the statistical test, it can be stated that in the case of variability in the number of bachelor's and master's degree graduates, there were no significant changes in the monitored years $\left(p_{\text {bachelor's degree }}=5.37015^{-41}, p_{\text {master's degree }}=6.75981^{-56}\right)$. However, in the case of a doctoral degree, $\mathrm{H} 0$ cannot be refuted $\left(\mathrm{p}_{\text {doctoral }}=0.71173\right)$.

\section{Discussion}

In this part, the research questions and hypotheses will be answered. RQ1: How many students graduated in the field of ICT?

The total numbers of ICT graduates varied considerably from 2010 to 2019. Most graduates were in the ICT field in 2013-2015, when the field of ICT was a promising field for many young people. In these years, 4,762 (2013), 4,468 (2014) and 4,599 (2015) graduates were recorded. After 2015, however, this interest dropped significantly. In the last monitored year (2019) there were only 3,638 graduates in the ICT field. This can be considered a problem especially for companies, which are forced due to constant technological development to expand the number of their employees by experts in the field of ICT.

Based on the performed chi-square test at the selected level, the significance of $\mathrm{p} 5 \%$ was refuted in the case of the bachelor's degree and the master's degree of study $\mathrm{H} 0$ and can therefore be considered a valid alternative hypothesis H1. However, in the case of the number of graduates of the doctoral study program, $\mathrm{H} 0$ was confirmed. However, in the case of digital transformation in HR in companies, it can be argued that this high level of education is not necessary for companies and the digital transformation of the HR system can also be carried out by bachelor's or master's degree graduates.

At the same time, it can be assumed that this can reduce the wage costs for these workers than in the case of employment of graduates with doctoral degrees. 


\section{Conclusion}

The aim of this paper was to determine the possible cause of lagging Czech companies in the field of HR transformation.

To achieve the set goal, one RQ was determined and the above hypothesis (H0) was further tested.

Based on the achieved results, it was found that the number of graduates in ICT fields has been declining recently, which could indicate that Czech companies do not have much opportunity to improve their position in the field of digitization in HR compared to other countries. However, the above hypothesis $\mathrm{H} 0$ was tested for clarification. Based on the performed statistical test, it was found that $\mathrm{H} 0$ cannot be refuted and digital transformation of the HR system can also be performed by graduates of bachelor's or master's studies.

However, based on the achieved results with a gradually increasing trend of demands on ICT professionals, it can be assumed that the need for graduates of ICT disciplines will continue to increase. In the following research, an analysis of the entire downward trend in the number of graduates could be performed with the identification of a specific moment when a critical shortage of graduates of ICT fields will be achieved. Last but not least, the creation of recommendations or methodologies to prevent this tragic scenario does not occur at all.

\section{References}

1. R. Kubík, Quantity and quality of human capital: Does the average years of schooling increase the quality of student? Littera Scripta, 6(1), 61-69 (2013)

2. C. Jane Hollowell, Z. Rowland, T. Klieštik, J. Klieštiková, V. V. Dengov, Customer loyalty in the sharing economy platforms: How digital personal reputation and feedback systems facilitate interaction and trust between strangers. Journal of Self-Governance and Management Economics, 7(1), 13-18 (2019)

3. M. Connolly-Barker, T. Klieštik, P. Šuleř, K. Zvaříková, Real-time decision-making in the information technology-driven economy: Planning, managing, and operating smart sustainable cities. Geopolitics, History, and International Relations, 12(1), 73-79 (2020)

4. E. Nica, V. Konečný, M. Poliak, T. Klieštik, Big data management of smart sustainable cities: Networked digital technologies and automated algorithmic decision-making processes. Management Research and Practice, 12(2), 48-57 (2020)

5. F. Míka, SystemOnline [online], Available at: https://m.systemonline.cz/hrmpersonalistika/digitalni-transformace-hr-zatim-pripomina-cekani-na-godota-1.htm (2017)

6. H. Kearney, T. Klieštik, M. Kováčová, M. Vochozka, The embedding of smart digital technologies within urban infrastructures: Governance networks, real-time data sustainability, and the cognitive internet of things. Geopolitics, History, and International Relations, 11(1), 98-103 (2019)

7. P. Malik, P. Garg, Learning organization and work engagement: the mediating role of employee resilience. The International Journal of Human Resource Management, 31(8), 1071-1094 (2020)

8. I. Krajnik, R. Demeter, The impact of digital technologies on accounting in light of the challenges of Society 5.0. Civil Szemle, 17(3), 115+(2020)

9. S. Grumbach, O. Hamant, Digital revolution or anthropocenic feedback? The Anthropocene Review, 5(1), 87-96 (2018) 
10. C. L. Chen, Y. C. Lin, W. H. Chen, C. F. Chao, H. Pandia, Role of government to enhance digital transformation in small service business. Sustainability, 13(3) (2021)

11. R. Maňák, Approach to human resources performance measurement. Littera Scripta, 6(1), 82-94 (2013)

12. M. Hajnic, B. M. Boshkoska, A disruptive decision support platform for reengineering the strategic transfer of employees. IEEE Access, 9, 29921-29928 (2021)

13. Dias R., N. Teixeira, V. Machová, P. Pardal, J. Horák, M. Vochozka, Random walks and market efficiency tests: Evidence on US, Chinese and European capital markets within the context of the global Covid-19 pandemic. Oeconomia Copernicana, 11(4), 585-608 (2020).

14. O. Lomakina, V. Kookueva, A. Makarenko, Redistribution of economic resources in the digital society. Business and Society Review, 126(1), 25-35 (2021)

15. Y. Kunii, T. Hasegawa, Fujitsu's activities to support digital transformation. Fujitsu Scientific \& Technical Journal, 55(1), 3-8 (2019)

16. S. Strohmeier, Digital human resource management: A conceptual clarification. German Journal of Human Resource Management: Zeitschrift für Personalforschung, 34(3), 345-365 (2020)

17. P. Dahlbom, N. Siikanen, P. Sajasalo, M. Jarvenpää, Big data and HR analytics in the digital era. Baltic Journal of Management, 15(1), 120-138 (2019)

18. F. Caputo, V. Cillo, E. Candelo, Y. P. Liu, Innovating through digital revolution. Management Decision, 57(8), 2032-2051 (2019)

19. J. Zhou, P. Li, Y. H. Zhou, B. C. Wang, J. Y. Zang, L. Meng, Toward new-generation intelligent manufacturing. Engineering, 4(1), 11-20 (2018)

20. M. Del Giudice, R. Chierici, A. Mazzucchelli, F. Fiano, Supply chain management in the era of circular economy: the moderating effect of big data. The International Journal of Logistics Management, 32(2) (2020)

21. L. Choain, T. Malzy, Leading change through your creative class. Journal of Organizational Change Management, 32(3), 377-384 (2019)

22. M. Diebig, F. Jungmann, A. Müller, I. C. Wulf, Content and process-related requirements for the risk assessment of psychological stress in the context of Industry 4.0. Zeitschrift für Arbeits-und Organisationspsychologie A\&O, 62(2), 53-67 (2018)

23. Czech Statistical Office. Digital economy in numbers [online], Available at: https://www.czso.cz/csu/czso/digitalni-ekonomika-vcislech?fbclid=IwAR1ZerEKXHQdKalIdMA16zQpPO7DSj9LCSaYPWt0FD3ym1ikcj 5pusdTTmE (2020) 